\title{
Women entrepreneurship in the MENA region: Factors influencing entrepreneurial motivation
}

\author{
TOUISSATE Hind ${ }^{1}$, Hassan AZDIMOUSA ${ }^{2}$ \\ ${ }^{1,2}$ Laboratory of Research in Organizational Management Sciences, LRSGO \\ Research Team «Etudes et Décisions Stratégiques, EDS » \\ Ecole Nationale de Commerce et de Gestion, \\ Ibn Tofail University of Kénitra - Morocco
}

\begin{abstract}
Women's entrepreneurship has been relevant for several years in the MENA region. It has been recognized as a lever for economic and social growth as well as a tool for job creation attracting more and more theorists and researchers from across the globe. In this particularly buoyant context, the goal of our research paper is to identify the factors influencing the motivation of women entrepreneurs in this region on the assumption that socio-cultural and individual factors are at the heart of women's entrepreneurship in the MENA region. The answers are supported through a qualitative study based on the empirical results of a survey of 45 innovative entrepreneurs from 10 different countries between 2017 and 2020 and based on an in-depth literature review.
\end{abstract}

Keywords: Female entrepreneurship, entrepreneurial motivation, push and pull factors, entrepreneurship, MENA region.

\section{INTRODUCTION}

Female entrepreneurship represents the fastest growing category of entrepreneurship in the world and one which received the attention of many academics in recent years. According to emerging literature, women can make a significant contribution to entrepreneurial activity (Noguera et al., 2013) and economic development (Kelley et al., 2017; Hechevarría et al., 2019) in terms of creating new jobs and increasing the gross domestic product (GDP) (Bahmani-Oskooee et al., 2013; Ayogu and Agu, 2015), with an additional positive impact on reducing poverty and social exclusion (Langowitz and Minniti , 2007; Rae, 2015). However, the percentage of women who decide to pursue an entrepreneurial career is lower than that of men (Elam et al., 2019).

Despite the MENA region making progress towards maturity, gender inequality prevails. Indeed, the 2018/2019 Global Entrepreneurship Monitor (GEM) Women's Entrepreneurship Report indicates that MENA countries have the highest gender inequalities in the world. Yet despite this gender gap, the same report shows that women are increasingly confident in starting their own businesses and indicates that the highest rates of female entrepreneurial intentions have been reported in the MENA region at 36.6\%, referring to a clear tendency of young women to start businesses in their respective countries.

In addition, the region shows the largest increase in female entrepreneurship motivations, at 35\%. Female entrepreneurship remains a major untapped resource in the North Africa and Middle East region (MENA region); a region where it is urgent to find new sources of growth and jobs. Thus, female entrepreneurship in this region still needs a better understanding. 
Considering the importance of female entrepreneurship as an economic lever in the MENA region, it is important to know more about the nature of the obstacles experienced by these women and to deepen the knowledge related to the strategies they have developed in the face of these issues in order to to propose tools to counter them.

Our study aims to shed light on obstacles faced by women entrepreneurs. To do this, we will ask a number of questions and hypotheses that we will try to answer: (1) Do women entrepreneurs in the MENA region face the same issues as those identified in the literature? (2) Do they have any issues related to the particularities of the MENA region? (3) What motivates these women and what are the solutions they adopt to counter the problems encountered?

Thus, the general question of our research translates as follows: What are the factors that affect women entrepreneurs in the MENA region and what are the solutions adopted to the different problems they face?

Our study explores the individual factors of women's entrepreneurial engagement in 10 MENA countries (Morocco, Algeria, Tunisia, Egypt, Jordan, Palestine, Lebanon, Saudi Arabia, Qatar, United Arab Emirates) and examines the challenges facing these women in their entrepreneurial journey. It first provides an overview of the theoretical background and presents the challenges facing women entrepreneurs in the MENA region. It then progresses to present the results of our study using a qualitative analysis of the data. The study ends with a discussion and reflection on the proposed results with the explicit aim of contributing to the knowledge gap on female entrepreneurship in the countries of the MENA region.

\section{WOMEN ENTREPRENEURS}

The definition of an entrepreneur does not seem to be unanimous among university researchers (Sharma and Chrisman, 1999). The entrepreneur is someone with the ability to recognize and evaluate a business opportunity. They are able to assemble the necessary resources and take advantage of them to initiate appropriate actions to ensure their success. (Chell, Haworth, Breurly, 1987; cited by Blawatt, 1995).

Timmons (1990) explained the entrepreneur's actions associated with the company's growth. For him, the entrepreneur is "an individual who establishes and runs a business with the goal of growing it and profiting from it. He is primarily innovative and employs strategic management practices in his company." The peculiarity of this definition is in the action of "establishing a business" which leads the reader to believe that to become an entrepreneur, an individual must start his business project from scratch.

Lavoie (1988), in his definition, considers purchasing or acceptancing the inheritance of shares just as acceptable as establishing a business. He describes the female entrepreneur as "a woman who alone or with partners has founded, purchased or inherited a business and assumes its financial, administrative and social responsibilities, and participates in its day-to-day management."

The authors agree that the entrepreneur is both the owner and manager of a business (Lavoie, 1988; Timmons, 1990). Thus, a woman entrepreneur can be defined as any woman who alone or with partners has founded, bought or inherited a business and assumes her financial, administrative and social decision-making responsibilities and also participates in its management and development to profit.

\section{The Motivations Of Women Entrepreneurs}

The literature distinguishes two factors that motivate women entrepreneurs to embark on the entrepreneurial journey: 
- The "pull" group: The creation of a business in this group is accomplished through the given opportunities or based on a personal choice. This implies the need for autonomy, personal achievement or the need to develop a product or service.

- The "push" group: The creation of a business in this group is done out of necessity, which implies the notion of forced choice, unemployment, family reasons, dismissal or the resumption of activity following the death of a father or spouse.

More specifically, Carrier et al. (2006) distinguish two lines of research in female entrepreneurship studies. The first group focuses on the motivations of women themselves (Belcourt (1990), Buttner and Moore (1997), Mattis (2000), Orhan and Scott (2001), Lambrecht et al. (2003)). The second tries to find the difference between men and women's behaviour in business (McGregor and Tweed, 2000; Kirkwood, 2003; Pikhala et al., 2000).

The following table summarizes the push / pull motivators of women entrepreneurs based on the study conducted by Fielden and Davidson in 2005 in 7 different countries: UK, Australia, India, Singapore, Holland and New Zealand.

TABLE I. MOTIVATIONS OF WOMEN ENTREPRENEURS

\begin{tabular}{|l|l|}
\hline \multicolumn{1}{|c|}{ Push factors } & \multicolumn{1}{c|}{ Pull factors } \\
\hline Lack of independence & Need for independence \\
Need of security & Achieve economic goals \\
Lack of flexibility & Flexibility \\
Not taken seriously & Personal determination \\
Pay inequality & Research of autonomy \\
Dissatisfaction at work & Become your own boss \\
Occupational segregation & Need to dominate \\
Family influence & Achieve personal ambitions \\
Discrimination & Self esteem \\
Glass ceiling & Financial independence \\
Lack of challenge & Make a difference \\
\hline
\end{tabular}

Source: Fielden and Davidson (2005)

In our study, we assume that economic, socio-cultural and individual factors are at the heart of women's entrepreneurship in the MENA region.

\section{FACTORS INFLUENCING THE ENTREPRENEURIAL DYNAMISM OF WOMEN}

In the various countries of the MENA region, the political, economic and socio-cultural context hinders women entrepreneurs from achieving their goals. Which prompts us to ask the following question: What 
motivates these women to be entrepreneurs in the MENA region? How can this context promote entrepreneurship?

The literature presents political, economic, socio-cultural and individual factors of female entrepreneurship. Their analysis recommends setting up a process of generating hypotheses that will be validated later on.

\section{A. Political factors}

Laws, policies and programs have a role in setting up trends as well as the potential of individuals, especially when it comes to choosing the type of entrepreneurial activities and accessing the means and services that encourage the process of starting a business. This is well evidenced in the analysis model of Shapero (Colot et al., 2007) and Gartner through state aid, the availability of support services and other government influences. The same model has been validated by Paturel and Arasti (2006). However, LeeGosselin, Housieaux and Villeneuve found in 2010 that women entrepreneurs perceive government programs to be too administratively burdensome and that this discourages them from taking an interest in them.

Ardagna and Lusardi (Renders, 2010) have highlighted the negative effect of the questionable quality of these institutions on entrepreneurship: it weakens the positive impact of social networks and reinforces the negative impact on taking risks.

\section{B. Economic factors}

In the light of several studies carried out, significant disparities exist in the access to finance by women entrepreneurs compared to their male counterparts. Rachdi (2006), Orser and Carrington (2005) as well as Amine and Staub (2011), explained the differences between women and men in accessing loans as follows:

1) Women and men bring a different type of expertise to the business (according to their education and years of experience);

2) Women are more likely to not register and legalize their businesses;

3) Women-owned businesses are relatively smaller and more likely to operate in sectors that are less promising;

4) Women entrepreneurs are less likely than men to seek equity financing.

\section{Sociocultural factors}

Bayad and Bourguiba (2006) cited by Colot (2007) evaluated the effect of culture on entrepreneurship based on the Hofstede cultural grid which states that a culture characterized by a low hierarchical distance, strong individualism, strong masculinity and a weak control of uncertainty are favorable to entrepreneurship. Using the same methodology, in the context of the MENA region, the influence of culture is manifested through its transmission of values and beliefs to individuals during socialization.

In most societies in the Middle East and North Africa, girls are taught from a very young age that their status depends more on their marital status and fertility than on their activity. Society therefore reserves a lower status for women, resulting in limited exercise of decision-making power and difficult access to education and resources. Given the influence of the aforementioned socialization, several recent research in entrepreneurship has emphasized the determining role of the relational network. In this sense, women who were born or placed within families with an entrepreneurial tradition or sense are more inclined to become entrepreneurs.

\section{Individual factors}

Shane, Locke and Collins (2003) developed an analytical framework in which the motivations of entrepreneurs are linked to the process of starting a business. In the set of indicators of motivation, they 
included the need for accomplishment, the propensity to take a risk, tolerance of ambiguity, self-control, individual efficiency, personal independence and the pursuit of goals.

For other researchers, these indicators are not independent but inter-correlated. In the cases of: the search for personal independence, the need for accomplishment and risk-taking. They have concluded that the people seeking personal independence have a strong need for accomplishment and take more calculated risks. These factors distinguish women entrepreneurs from each other and influence the desirability of starting a business. This so-called drive, according to Shane, Locke and Collins (2003), encompasses ambition, energy and tenacity. These factors also determine the entrepreneurial process. If Brouillard (2005) is to be taken in consideration, we can also say that there is a connection between passion, drive and motivation, but much previous research did not address it.

Other interesting analysis schemes are those of Morisson (2001) and Davidson (1995) in which the personal characteristics of the entrepreneur are linked to the creation of businesses. These characteristics are demographic and boil down to gender, age, marital status, family background, education level, experience, family status and reasons for going into business.

Gender differences were observed on many levels: Education, Management experience, financial and networking skills and the motivation of starting a business.

\section{Methodology}

After defining the concept of female entrepreneurship and studying the elements of entrepreneurial motivation in the Push and Pull theory and the factors that are more likely to influence the entrepreneurial dynamism of women, we decided to carry out a field study in order to identify the motivation of female entrepreneurs in the MENA region and to verify if the political, economic, socio-cultural and individual factors have an impact on the nature of the motivation underlying their decision to become entrepreneurs.

As part of our study, we adopted a qualitative approach which aims to identify themes, points of attachment and points of approach related to the topic of our study. We conducted 45 semi-structured interviews and we targeted women entrepreneurs in the formal sector who have created, inherited or taken over a legally registered business and who participated in making strategic decisions. The data on which our study is based was collected from women living and working in Morocco, Algeria, Tunisia, Egypt, Lebanon, Jordan, Palestine, Saudi Arabia, Qatar and the United Arab Emirates. These 10 countries represent a variety of geographic regions, sizes, cultures and levels of economic development.

The entrepreneurs answered a series of 25 questions concerning: their entrepreneurial motivations; their management styles; obstacles to growth; their views on innovation; the various networks and support systems.

According to the study entitled "Women Entrepreneurs in the Middle East and North Africa: Characteristics, Contributions and Challenges" conducted by the International Finance Corporation (IFC) and the Center of Arab Women for Training and Research (CAWTAR), "Women entrepreneurs in the MENA region start their entrepreneurial activities mainly between the ages of 25 and 35." On this basis, our target group age was fixed between 25 and 35 years old. They mainly come from middle and upper socio-economic backgrounds, which gave them access to higher education levels.

In fact, $80 \%$ of women entrepreneurs who participated in this study graduated from university. 12 businesses had less than 10 employees and were classified as small businesses and 35 organizations had under 125 employees and were classified as medium-sized businesses. The targeted companies were mainly focused 
on the fields of education, crafts, jewelry, textiles and food industry. They were created between 2004 and 2016 and most of the women interviewed were founders, directors or held important decision-making positions.

In our survey, the characteristics of the entrepreneur were discussed first. This section is based on questions related to age, marital status, number of children, education and occupation in the organization. In the first part, the women are invited to explain the reasons for which they created their businesses. In the second part, we looked at the characteristics of the companies created: date of creation, size, location, sector of activity and performance. We then looked at the factors that motivate them to take up business and if the political, economic, socio-cultural and individual factors have an impact on the nature of their motivation.

\section{Results}

In the various countries of the MENA region, the political, economic and socio-cultural context hinders women entrepreneurs who become an example of courage and resistance when they start a business. The responses we were able to collect from our sample of 45 women entrepreneurs allowed us to disclose their motivations for theoretical validation.

Based on their economic and social circumstances, women in the MENA region choose entrepreneurship for several reasons. They can be driven by economic necessity as a means to fight unemployment, as well as to gain power and respect and assert oneself in their family and in society. It is also a way to satisfy their need for emancipation in order to gain more independence and fight injustice and male hegemony in their society. Women entrepreneurs in the MENA region unanimously shared that the economic necessity is behind their choice to launch their entrepreneurial activity and some of them added that this motivation hides behind it other motivations such as self-confirmation and the desire for autonomy and personal emancipation.

The fight against the socio-cultural constraints that mark the countries of the MENA region is among the objectives of female entrepreneurship, especially in a society that considers the role and the natural position of women is to stay at home, to serve her family.

According to one of the women we interviewed, "a woman's position in her society is reflected in her economic self-sufficiency". Female entrepreneurship therefore brings status and social recognition to women. This is why entrepreneurship is seen as a way to gain power and respect in society by many women. Entrepreneurship is also seen by the majority of women entrepreneurs in our sample as an outcome that allows them to free themselves from social injustice and the hegemony of a male society.

\section{DiscuSSION}

Several factors have been shared by the interviewed women explaining the reason behind their choices of the field of entrepreneurship and starting their own business. The replies we collected indicate that women in the MENA region are relatively motivated.

27 women said that they were motivated to start a business out of economic necessity rather than opportunity. This category corresponds to women with a high level of education but unfavorable economic conditions and who struggled to enter the labor market after graduation. The other category entered the world of entrepreneurship for various reasons which can be summarized as follows: to have more income, because of physical or moral harassment, because of the boredom of routine or because of unambitious salaried work; they have left their jobs and created their own businesses.

The results also showed that female entrepreneurs in the MENA region are motivated by the desire to assert themselves in a society where traditional culture is predominant. This result was confirmed by Collins (2007) 
who identified the need for recognition and self-esteem among the most important motivators of women entrepreneurs.

Moreover, the results showed that women entrepreneurs in the MENA region want to help their families. So the financial aspect of entrepreneurship against unemployment and to improve their socio-economic status is important. This result was confirmed by Hani (2015) who showed that entrepreneurship is an important means of income for any woman in a developing country.

In a society where a woman must always ask her family's permission to go out and sometimes to work, the desire for autonomy remains an important goal to achieve. Several women have turned to entrepreneurship as a means to exercise this independence. This is in line with the results of Stephan, Hart and Drew (2015) who found that women entrepreneurs are motivated by independence.

For these women, entrepreneurship is seen as a way of breaking from the situation of inactivity, unemployment and marginalization of which they may be victims, especially with the instability of the labor market in the MENA region and the quality of precarious jobs offered to women.

Thus, the result of our survey is reassuring, women entrepreneurs in the MENA region have shown a real desire to continue working in their respective fields, they are motivated and ambitious and all seek a balance between their personal and professional life.

\section{Conclusion}

The study on the entrepreneurial motivation of women entrepreneurs in the MENA region allowed us to shed light on the complexity of the motivational phenomenon, which brings together several dimensions. All of these dimensions can be summarized in economic and non-economic, positive and negative motivational factors.

Women entrepreneurs from across the MENA region have challenged inequalities and claimed their professional positions. They are now recognized as a very important element of society that promotes development, both economic and social. However, their number remains very low compared to developed countries, but remains reassuring. The lack of professional networks, the lack of support, funding problems and other factors are causing this drop in the rate of female entrepreneurship in the MENA region.

At the end of our research work, we were able to observe through the responses collected in the framework of our survey that the fact of becoming a woman entrepreneur no longer frightens them today, they are more and more keen on starting a business. They desire more freedom, and seek to challenge each other constantly. For them, the fact of becoming an entrepreneur represents a dream to achieve, and a passion to satisfy, but most importantly a means to gain financial independence which also helps to develop the local and regional economy.

This study can also help to develop the skills of women entrepreneurs, improving their ability to get involved in business activities and this through the identification of strategies that make it possible to overcome cultural, legal, financial and training constraints.

One of the limitations of this study is that the literature on female entrepreneurship in MENA countries is limited. It is therefore difficult to compare search results with similar publications in the same context.

Since the engagement of women entrepreneurs offers new prospects for economic development, more initiatives should be encouraged through the establishment of national support plans for any woman with the 
motivation to become an entrepreneur. Investment programs must be offered to their benefit and more social policies must eliminate discriminatory aspects that may limit their participation in the economy, in order to offer them equal opportunities. New lines of research can thus be suggested to study the specificities of entrepreneurial motivation of women in the MENA region in order to improve our understanding of this field of research and to broaden the scope of the results towards professionals and political decision makers.

Finally, women constitute a real economic and social asset for their countries and it would be more judicious to train them from their youngest age to the profession of entrepreneurship, and to establish the necessary measures to facilitate their access to getting loans of all kinds because they contribute to both the wealth of their families and countries and create jobs for other women which will help fight unemployment.

\section{REFERENCES}

[1] Anderson, E \& Roland T. Rust (1997), "Customer Satisfaction, Productivity, and Profitability: Differences Between Goods and Services," Marketing Science, 16 (2), pp.129-45.

[2] Amine L. \& Staub K. (2011), "Women entrepreneurship in sub-Saharan Africa: An institutional theory analysis from a social marketing point of view." Entrepreneurship \& Regional Development, 21:2, pp.183- 211.

[3] Ardagna, S. \& Lusardi, A.M. (2010), "Explaining International Differences in Entrepreneurship: The Role of Individual Characteristics and Regulatory Constraints, in Lerner, J. and A. Schoar (eds.)," International Differences in Entrepreneurship, Chicago, University of Chicago Press, pp.17-62.

[4] Ayogu, D. U., and Agu, E. O. (2015). Assessment of the contribution of women entrepreneurs towards entrepreneurship development in Nigeria. Intern. J. Curr. Res. Acad. Rev. 3, 190-207.

[5] Bahmani-Oskooee, M., Kutan, M. A., and Xi, D. (2013). The impact of economic and monetary uncertainty on the demand for money in emerging economies. Appl. Econ. 45, 3278-3287.

[6] Belcourt, M. (1990), "A family portrait of Canada's most successful female entrepreneurs." Journal of Business Ethics, 9(4-5), pp. 435-438.

[7] Brouillard, F. (2005), "Facteurs de motivation à démarrer une entreprise en Abitibi-Témiscamingue" Mémoire de maîtrise, Université du Québec à Chicoutimi et Université du Québec en Abitibi-Témiscamingue, Rouyn-Noranda.

[8] Blawatt, K. (1995), "Defining the Entrepreneur: A Conceptual Model of Entrepreneurship," Actes du Conseil Canadien de la PME et de l'Entrepreneuriat, CCPME, 12e Colloque, Thunder Bay, Ontario, Octobre, pp. 13-37.

[9] Buttner E. \& Moore D. (1997), “Women's Organizational Exodus to Entrepreneurship: Self Reported Motivations and Correlates with Success." Journal of Small Business Management 35(1), pp. 34-46.

[10] Carrier, C., Julien, P.A., Menvielle, W. (2006), "Un regard critique sur l'entrepreneuriat féminin: une synthèse des études des 25 dernières années," Gestion, 31 (2), pp. 36-50.

[11] Carsrud A., Brannback M. (2011), “Entrepreneurial Motivations: What Do We Still Need to Know?” Journal of Small Business Management, Vol. 49, $\mathrm{n}^{\circ}$ 1, pp. 9-26.

[12] Colot O. (2007), "Expliquer le phénomène entrepreneurial: les variables environnementales," Actes du colloque "Entrepreneuriat: Nouveaux défis, nouveaux comportements" Cahiers de la Recherche de l'ISC de Paris, pp. 82-97.

[13] Davidson. P. (1995), "Determinants of entrepreneurial intentions", Paper presented at the RENT IX Workshop, Piacenza, Italy, Nov. 23-24.

[14] Elam, A. B., Brush, C. G., Greene, P. G., Baumer, B., Dean, M., and Heavlow, R. (2019). Global Entrepreneurship Monitor 2018/2019 Women's Entrepreneurship Report. Babson College: Smith College and the Global Entrepreneurship Research Association.

[15] Fielden, Sandra \& Davidson, M.J. (2005), "The way forward for women business owners." pp.264-271

[16] Hani F. (2015), "Entrepreneurial Motivation and Challenges: A study on women entrepreneurs in Sylhet City. Bangladesh" Global Disclosure of Economics and Business, Volume 4, No 2/2015, pp. 4-8

[17] Hechevarría, D., Bullough, A., Brush, C., and Edelman, L. (2019). High-growth women's entrepreneurship: fueling social and economic development. J. Small Business Managem. 
[18] Kelley, D. J., Baumer, B. S., Brush, C., Green, P. G., Mahdavi, M., Majbouri, M., et al. (2017). Global Entrepreneurship Monitor 2018/2017 Report on Women's Entrepreneurship. Babson College: Smith College and the Global Entrepreneurship Research Association.

[19] Kirkwood, J. (2003), "The motivation of entrepreneurs: Comparing women and men" In 48th World Conference of the ICSB, Belfast, Northern Ireland, June. Budgeting and locus of control,” Accounting review Vol. 61, pp. 112-118.

[20] Lambrecht, J., Pirnay, F., Amedodji, P., Aouni, Z. (2003), "Entrepreneuriat féminin en Wallonie, Centre de Recherche PME et d'Entrepreneuriat, Université de Liège et Centre d'Études pour l'Entrepreneuriat, EHSAL, p. 231.

[21] Langowitz, N., and Minniti, M. (2007). The entrepreneurial propensity of women. Entrepreneurship 31, 341-364.

[22] Lavoie, D (1988), "Les entrepreneures : pour une économie canadienne renouvelée,” Conseil consultatif canadien sur la situation de la femme, Ottawa, février 1988, p. 64.

[23] Lee-gosselin H., Housieaux C. and Villeneuve M. (2010), "Réalités, besoins et défis des femmes entrepreneures de la région de la Capitale-Nationale," Étude réalisée dans le cadre de la mise en œuvre de l’Entente spécifique en matière de condition féminine dans la région de la Capitale Nationale, Université de Laval, Canada, p. 108.

[24] Mattis, M. C. (2000), "Women entrepreneurs in the United States." in Women in management: Current research issues, 2, eds. MJ Davidson \& RJ Burke, pp. 53-68.

[25] Mcgregor, J., \& Tweed, D. (2000), “Women managers and business owners in New Zealand.” Women in management: Current research issues, 2, pp. 40-52.

[26] Morisson (2001), “Entrepreneurs transcends time: a biographical analysis”, Management decision, vol. 39, n9, pp. 784-791.

[27] Noguera, M., Álvarez, C., and Urbano, D. (2013). Socio-cultural factors and female entrepreneurship. Intern. Entrepreneurship Managem. J. 9, 183-198.

[28] Orhan, M. \& Scott, D. (2001), "Why women enter into entrepreneurship: An explanatory model." Women in Management Review, 16, pp. 232-243.

[29] Orser B. \& Carrington C. (2005), "Les femmes entrepreneurs et le capital financier" Atelier PRF, PME organisé par le Gouvernement du Canada le 21 septembre 2006 dans le cadre de son programme de recherche sur le financement des PME.

[30] Paturel R. \& Arasti Z. (2006), "Les principaux déterminants de l'entrepreneuriat féminin en Iran”, Papier présenté au Congrès International Francophone en Entrepreneuriat et PME sur le thème "L'Internationalisation des PME et ses conséquences sur les stratégies entrepreneuriales”, 25-26 octobre 2006, Haute École de Gestion (HEG) Fribourg, Suisse.

[31] Pikhala, T., Vesalainen, J., Vital, R., (2000), "Motivational background as an explanation for differences between male and female entrepreneurship," Actes de la 45ème conférence de l'International Council for Small Business, Brisbane, Australie.

[32] Rae, D. (2015). Opportunity-Centred Entrepreneurship. New York, NY: Palgrave McMillan.

[33] Rachdi F. (2006), “L’entrepreneuriat féminin au Maroc : une étude exploratoire” Papier présenté au Congrès International Francophone en entrepreneuriat et PME sur le thème «L'internationalisation des PME et ses conséquences sur les stratégies entrepreneuriales, 25-27 octobre 2006, Haute école de gestion (HEG), Fribourg, Suisse.

[34] Shane S., Locke E., Collins C. (2003), “Entrepreneurial Motivation”, Human Resource Management Review, Vol. 13, pp. 257 279.

[35] Sharma, P. \& Chrisman, J. J. (1999), "Toward a reconciliation of the definitional issues in the field of corporate entrepreneurship" Entrepreneurship Theory and Practice, 23(3), pp. 11- 26.

[36] Stephan, U., Hart, M. \& Drews, C.C. (2015), "Understanding motivations for entrepreneurship: a review of recent research evidence" Birmingham (UK): Enterprise Research Centre, pp. 12-16.

[37] Timmons, J. (1990), “Entrepreneurial Mind: Winning Strategies for Starting, Renewing and Harvesting,” Brick House Publishing Company, 1-208

[38] World Bank (2007), “The Environment for Women's Entrepreneurship in the Middle East and North Africa Region”, The World Bank, Washington, DC 